\title{
Epidemiology of respiratory viral infections in two long-term refugee camps in Kenya, 2007-2010
}

\author{
Jamal A Ahmed ${ }^{1,7^{*}}$, Mark A Katz ${ }^{1}$, Eric Auko ${ }^{2}$, M Kariuki Njenga', Michelle Weinberg ${ }^{3}$, Bryan K Kapella ${ }^{3}$, \\ Heather Burke', Raymond Nyoka', Anthony Gichangi', Lilian W Waiboci', Abdirahman Mahamud², \\ Mohamed Qassim ${ }^{4}$, Babu Swai ${ }^{4}$, Burton Wagacha ${ }^{4}$, David Mutonga ${ }^{5}$, Margaret Nguhi ${ }^{6}$, Robert F Breiman ${ }^{1}$ and \\ Rachel B Eidex ${ }^{1}$
}

\begin{abstract}
Background: Refugees are at risk for poor outcomes from acute respiratory infections (ARI) because of overcrowding, suboptimal living conditions, and malnutrition. We implemented surveillance for respiratory viruses in Dadaab and Kakuma refugee camps in Kenya to characterize their role in the epidemiology of ARI among refugees.
\end{abstract}

Methods: From 1 September 2007 through 31 August 2010, we obtained nasopharyngeal (NP) and oropharyngeal (OP) specimens from patients with influenza-like illness (ILI) or severe acute respiratory infections (SARI) and tested them by RT-PCR for adenovirus (AdV), respiratory syncytial virus (RSV), human metapneumovirus (hMPV),

parainfluenza viruses (PIV), and influenza A and B viruses. Definitions for ILI and SARI were adapted from those of the World Health Organization. Proportions of cases associated with viral aetiology were calculated by camp and by clinical case definition. In addition, for children $<5$ years only, crude estimates of rates due to SARI per 1000 were obtained.

Results: We tested specimens from $1815 \mathrm{ILI}$ and 4449 SARI patients (median age $=1$ year). Proportion positive for virus were AdV, 21.7\%; RSV, 12.5\%; hMPV, 5.7\%; PIV, 9.4\%; influenza A, 9.7\%; and influenza B, 2.6\%; 49.8\% were positive for at least one virus. The annual rate of SARI hospitalisation for 2007-2010 was 57 per 1000 children per year. Virus-positive hospitalisation rates were 14 for AdV; 9 for RSV; 6 for PIV; 4 for hMPV; 5 for influenza A; and 1 for influenza B. The rate of SARI hospitalisation was highest in children $<1$ year old (156 per 1000 child-years). The ratio of rates for children $<1$ year and 1 to $<5$ years old was 3.7:1 for AdV, 5.5:1 for RSV, 4.4:1 for PIV, 5.1:1 for hMPV, 3.2:1 for influenza A, and 2.2:1 for influenza B. While SARI hospitalisation rates peaked from November to February in Dadaab, no distinct seasonality was observed in Kakuma.

Conclusions: Respiratory viral infections, particularly RSV and AdV, were associated with high rates of illness and make up a substantial portion of respiratory infection in these two refugee settings.

\section{Background}

The World Health Organization (WHO) estimates that acute lower respiratory infections (ALRI) cause nearly four million deaths per year, a rate of more than 60 deaths/100,000 population [1]. Rates are even higher in developing countries, where pneumonia is responsible for an estimated $10-25 \%$ of all deaths among children under 5 years of age [2]. While bacterial infections,

\footnotetext{
* Correspondence: JAhmed@ke.cdc.gov

'US Centers for Disease Control and Prevention, Nairobi, Kenya

Full list of author information is available at the end of the article
}

especially due to Streptococcus pneumoniae, are critically important, viral causes are also associated with a substantial proportion of ALRI [3-7]. Viral infections can exacerbate chronic or recurring respiratory conditions, including asthma, thus representing an additional burden of respiratory viruses $[8,9]$.

Respiratory syncytial virus (RSV) and influenza viruses are important pathogens in childhood pneumonia, and primary infection with these two pathogens predisposes children to secondary bacterial pneumonia, especially in children $<2$ years old $[4,6,7,10,11]$. RSV has been

\section{Biomed Central}


identified in 15-40\% of cases in hospitalised children, while human metapneumovirus (hMPV) and parainfluenza viruses (PIV) are associated with a substantial proportion of ALRI in infants and young children; asymptomatic infection with these pathogens appears uncommon [4,6,7,12-14]. The United Nations High Commissioner for Refugees (UNHCR) reports ALRI as the leading cause of mortality and morbidity among refugees in Kenya, where $30-40 \%$ of deaths of children < 5 years of age and up to $45 \%$ of morbidity is associated with acute respiratory infections $[1,15]$. For viral respiratory pathogens, vaccines are currently available only to prevent influenza; however, vaccine research and development are focusing on many other leading viral pathogens [10,16-18]. Understanding the epidemiology of specific aetiologies of ALRI in Africa is therefore important if maximal benefit is to be obtained from new vaccine developments [19].

Displaced populations, including refugees, are at risk for negative outcomes secondary to ALRI because of malnutrition, poor living conditions, and overcrowding [12,20-22]. At the end of 2009, there were 15.2 million refugees in the world, and some 5.2 million were in protracted situations [23]. Due to chronic intractable conflicts in some parts of the world, many refugees live in longterm camps for years or decades, with unique challenges that are often as difficult as the crisis management necessary during the emergency phase of refugee relief operations [24]. In some settings, additional challenges are posed by sustained or intermittent bursts of large numbers of new refugee arrivals from areas of renewed conflict [23].

In 2006, as the concern for human pandemic influenza grew, the Kenya Ministry of Health, in collaboration with the United States Centers for Disease Control and Prevention (CDC), established a nationwide facilitybased influenza sentinel surveillance network comprising 11 sites, including Kakuma and Dadaab refugee camps [25]. The objective was to characterize the epidemiology of seasonal influenza and to detect novel influenza virus strains. In 2007, we expanded testing at the two refugee camps to include other respiratory viruses, with the aim of determining a broader range of viral aetiologies of acute respiratory infections (ARI). We present the results of 3 years of this surveillance.

\section{Methods}

\section{Site and population}

From September 2007 to August 2010, surveillance was conducted in Dadaab and Kakuma refugee camps, located in east and northwest Kenya, respectively. Dadaab is a large refugee camp complex and consists of three camps-Hagadera, Ifo and Dagahaley. Each camp has at least four health posts, which serve only outpatients, and one hospital with both inpatient and outpatient facilities. The refugee population in Dadaab has grown by more than $150 \%$ since the onset of surveillance, and as of August 2010, there were approximately 305,000 registered refugees. Kakuma had about 70,000 refugees throughout the study period and has three outpatient clinics and one hospital. Health care facilities in both camps serve the refugee population and the local Kenyan population.

In each camp, one hospital and one outpatient clinic were chosen as sentinel sites for surveillance. In Dadaab refugee camp complex, Hagadera hospital and one Hagadera health post were chosen as sentinel sites for Dadaab because at the start of the project, they were the busiest health facilities. In Kakuma, in addition to the only hospital, one outpatient clinic was selected. The two hospitals are the only facilities that offer inpatient services for refugees in Kakuma and Hagadera, Dadaab. They account for almost all hospitalisations.

\section{Case definitions}

At both sites we enrolled patients with influenza-like illness (ILI) and severe acute respiratory illness (SARI). Definitions for ILI and SARI were adapted from those of the WHO [26-28].

- ILI was defined as fever $\geq 38^{\circ} \mathrm{C}$ and cough or sore throat.

- For children $>1$ week and $<2$ months old, SARI was defined as an admission to the paediatric ward with any of the following: respiratory rate $>60$ per minute, severe chest indrawing, nasal flaring, grunting, fever $\geq 38^{\circ} \mathrm{C}$, hypothermia $<35.5^{\circ} \mathrm{C}$, or pulse oxygenation $<90 \%$.

- For children 2 months to $<5$ years of age, SARI was defined as cough or difficulty breathing and any one of the following: respiratory rate $>50 / \mathrm{min}$ for infants 2 months to $<1$ year old or $>40 / \mathrm{min}$ for children 1 to $<5$ years old, chest indrawing or stridor in a calm child, unable to drink or breast feed, vomiting, convulsions, lethargic or unconscious, or pulse oxygen saturation $<90 \%$.

- For older children and adults $\geq 5$ years of age, SARI was defined as fever $\geq 38^{\circ} \mathrm{C}$, and cough or sore throat, and shortness of breath or difficulty breathing.

hospitalisation was a required part of the SARI case definition in all ages. For every patient, surveillance officers recorded specific signs and symptoms so that case classification could be validated. The maximum number of eligible ILI patients was limited to the first three cases per day for both sites.

\section{Clinical specimens}

Trained surveillance officers identified eligible patients, administered a standardised questionnaire, and obtained nasopharyngeal (NP) and oropharyngeal (OP) swab specimens for diagnostic testing. NP and OP swab specimens were obtained according to the following 
procedure: a) a sterile nylon flocked plastic-shafted OP swab (503CS01, Copan Diagnostics, Murrieta, CA, USA) was used to rub the back of the oropharyngeal mucosal membrane for 3-5 s and then placed into $1 \mathrm{~mL}$ of viral transport media; b) a polyester-tipped flexible aluminium-shafted NP swab was inserted into the nose until it reached the nasopharynx, where it was rotated $180^{\circ}$ and left in place for 3-5 s. The swab was inserted into a 1-mL vial of viral transport media. The cryovials were stored in a refrigerator at the health care facility and kept at $2-8^{\circ} \mathrm{C}$ for up to $96 \mathrm{~h}$; the vials were then shipped to the Kenya Medical Research Institute (KEMRI)/CDC laboratory in Nairobi. Transportation to and from Dadaab and Kakuma is severely restricted; air transport is not always guaranteed, and flights are regularly diverted or cancelled with little or no notice. Considering their time-sensitivity, specimens were obtained only if they could be shipped within $96 \mathrm{~h}$ of collection. For two of the 3 years reported in this study, the NP and OP specimens were inserted into the same vial and tested as one specimen while in the final year the specimens were placed in separate vials in which case a positive result from either specimen was sufficient to classify a case as positive [29].

\section{Specimen processing}

Specimens were not tested if the following conditions existed when the specimen arrived at the lab: the swab was missing; the volume was less than $600 \mu \mathrm{L}$; the specimen was at room temperature; patient identification was absent or incomplete; or the patient questionnaire was absent. In addition, the test results were discarded for any specimen whose human ribonuclease P (RNP) gene (internal control) was negative. Testing for respiratory viruses was carried out by real-time reverse transcriptase polymerase chain reaction (RT-PCR) at the KEMRI/CDC laboratory. An aliquot of each respiratory specimen was tested for influenza A and B viruses, respiratory syncytial virus (RSV), adenovirus (AdV), human parainfluenza viruses 1, 2 and 3 (PIV), and human metapneumovirus (hMPV). Details of the procedures used are described elsewhere [29-31].

\section{Data collection, entry, and analysis}

For every ILI and SARI case enrolled, a brief standardized questionnaire was completed by staff at the health care facility. Demographic information, medical information, and a history of influenza vaccination were obtained directly from adult patients and from the parent or guardian for minors. Data were entered into a Microsoft Access database (Microsoft Corporation, Washington, USA) and analysed by SAS system for Windows, version 9.1 (SAS Institute Inc, Cary, North Carolina, USA) and Microsoft Excel (Microsoft Corporation, Washington,
USA). Crude estimates of rates of hospitalisation per 1000 due to SARI for children $<5$ years old were calculated by dividing the number of SARI cases among children $<5$ years old by the population of that age group in the camp. Because the two hospitals are the only inpatient facilities in the respective camps and account for almost all admissions, we did not adjust for out-of-camp hospitalisation. Monthly population data for Hagadera, Dadaab and Kakuma camps for the months of September 2007 to August 2010 were obtained from the UNHCR Health Information System [32]. Population figures for Hagadera for December 2008 were not available, so we estimated the December 2008 population as the average of the months of November 2008 and January 2009. The 95\% confidence intervals were calculated by using the Poisson distribution [33,34]. Rates were also estimated for the $<1$ year and 1 - to $<5$-year age groups and by location and viral aetiology. When calculating these rates, Kenyan nationals were not included in the numerator, because population estimates for the local (non-refugee) population were not known. We were interested in calculating rates for acute onset illnesses; therefore, SARI cases with symptom onset of $>14$ days were excluded. Rates were not calculated for children $\geq 5$ years old and adults because reliable denominator data was not available.

Ethical approval for the surveillance activities was obtained from the KEMRI Ethical Review Committee (SSC Protocol Number 1161). Institutional review was waived by CDC because the study was considered to be a non-research public health activity. Informed written consent was obtained from all participants and from the guardians of minors.

\section{Results}

During the study period, 6,647 patients meeting case definitions for ILI and SARI were enrolled. Specimens from 268 participants were discarded in the field before shipment (shipment did not occur in time) and an additional 115 specimens were rejected by the laboratory because of poor sample quality (see methods). Specimens from 6,264 participants were tested: 3,323 (53.0\%) were from Kakuma and 2,941 (47.0\%) were from Dadaab; 3,394 (54.2\%) were from males (Table 1). There were 2,292 (36.6\%) children < 1 year, 2846 (45.4\%) 1-4 years, and $1,126(18.0 \%) \geq 5$ years old. The median age was 1 year (range: 1 month-84 years), and the median number of days between symptom onset and enrolment was 2 days (range: 0-38 days). A total of 6,179 (99.2\%) and 6,217 (99.8\%) were enrolled within 7 days and 14 days of symptom onset, respectively. Date of symptom onset was not recorded for 32 patients. Participants were mainly refugees from Somalia (3,891 [62.1\%]), Sudan (1,441 [23.0\%]), Ethiopia (183 [2.9\%]), and from other countries in east and central Africa (158 [2.5\%]). 
Table 1 Demographic distribution and viral prevalence in specimens tested, by camp, Kenya, September 2007-August 2010

\begin{tabular}{|c|c|c|c|c|c|}
\hline & \multirow{2}{*}{$\begin{array}{c}\text { Total }(\mathrm{N}=6264) \\
n(\%)\end{array}$} & \multicolumn{2}{|c|}{ Location } & \multicolumn{2}{|c|}{ Case classification } \\
\hline & & $\begin{array}{l}\text { Kakuma }(\mathrm{N}=3323) \\
n(\%)\end{array}$ & $\begin{array}{l}\text { Dadaab }(\mathrm{N}=2941) \\
n(\%)\end{array}$ & $\begin{array}{l}\mathrm{ILI}^{1} \\
(\mathrm{~N}=1815) \\
n(\%)\end{array}$ & $\begin{array}{l}\text { SARI }^{2} \\
(\mathrm{~N}=4449) \\
n(\%)\end{array}$ \\
\hline \multicolumn{6}{|l|}{ Gender } \\
\hline Male & $3394(54.2)$ & $1800(54.2)$ & $1594(54.2)$ & $939(51.7)$ & $2455(55.2)$ \\
\hline Female & $2870(45.8)$ & $1523(45.8)$ & $1347(45.8)$ & $876(48.3)$ & $1994(44.8)$ \\
\hline \multicolumn{6}{|l|}{ Age } \\
\hline$<1$ years & 2292 (36.6) & $1228(37.0)$ & $1064(36.2)$ & $520(28.7)$ & $1772(39.8)$ \\
\hline $1-<2$ years & $1379(22.0)$ & $798(24.0)$ & $581(19.8)$ & $361(19.9)$ & $1018(22.9)$ \\
\hline $2-<5$ years & $1467(23.4)$ & $815(24.5)$ & $652(22.2)$ & $497(27.4)$ & $970(21.8)$ \\
\hline$\geq 5$ years & $1126(18.0)$ & $482(14.5)$ & $644(21.9)$ & $437(24.1)$ & $689(15.5)$ \\
\hline \multicolumn{6}{|l|}{ Nationality } \\
\hline Somali & 3891 (62.1) & $980(29.5)$ & $2911(99.0)$ & $996(54.9)$ & $2895(65.1)$ \\
\hline Sudanese & $1441(23.0)$ & $1431(43.1)$ & $10(0.3)$ & $407(22.4)$ & $1034(23.2)$ \\
\hline Kenyan & $591(9.4)$ & $578(17.4)$ & $13(0.4)$ & $315(17.4)$ & $276(6.2)$ \\
\hline Ethiopian & $183(2.9)$ & $178(5.4)$ & $5(0.2)$ & $59(3.6)$ & $124(2.8)$ \\
\hline Other ${ }^{3}$ & $158(2.5)$ & $156(4.7)$ & $2(0.1)$ & $38(2.1)$ & $120(2.7)$ \\
\hline \multicolumn{6}{|l|}{ Infection prevalence } \\
\hline Adenovirus & $1361(21.7)$ & $815(24.5)$ & $546(18.6)$ & $352(19.4)$ & $1009(22.7)$ \\
\hline RSV & $781(12.5)$ & $364(11.0)$ & $417(14.2)$ & $155(8.5)$ & $626(14.1)$ \\
\hline hMPV & $359(5.7)$ & $180(5.4)$ & $179(6.1)$ & $93(5.1)$ & $266(6.0)$ \\
\hline Parainfluenza & $591(9.4)$ & 319 (9.6) & $272(9.3)$ & $155(8.5)$ & $436(9.8)$ \\
\hline Influenza A & $607(9.7)$ & $300(9.0)$ & $307(10.4)$ & $197(10.9)$ & $410(9.2)$ \\
\hline Influenza B & $161(2.6)$ & $75(2.3)$ & $86(2.9)$ & $55(3.0)$ & $106(2.4)$ \\
\hline At least one virus & $3119(49.8)$ & $1642(49.4)$ & $1477(50.2)$ & $837(46.1)$ & $2282(51.3)$ \\
\hline
\end{tabular}

${ }^{1}$ Influenza-like illness; ${ }^{2}$ Severe acute respiratory infection; ${ }^{3}$ Burundi, Democratic Republic of Congo, Rwanda, Uganda

Only 591 (9.4\%) were Kenyan nationals receiving care at the refugee health facilities (Table 1). No participant had been vaccinated for influenza prior to being enrolled and tested.

Of the 6,264 tested, illnesses for 4,449 (71.0\%) were classified as SARI and for 1,815 (29.0\%) as ILI; 3,119 (49.8\%) were positive for at least one virus (Table 1 ). The numbers and proportions of specimens positive for respiratory viruses were: AdV, 1361 (21.7\%); RSV, 781 (12.5\%); hMPV, 359(5.7\%); PIV, 591 (9.4\%); influenza A, 607 (9.7\%); and influenza B, 161 (2.6\%) (Table 1). Children $<1$ year old accounted for $47.0 \%$ of RSV-positive patients, compared with $38.1 \%$ for $\mathrm{AdV}, 40.4 \%$ for hMPV, 41.1\% for PIV, 27.3\% for influenza A, and 23.0\% influenza B (Figure 1). Table 1 below also shows proportion positive for virus by refugee camp and by case classification.

\section{Rates of hospitalisation}

The annual crude rate of SARI hospitalisation for 20072010 was 57 per 1000 children < 5 years old per year (Table 2). Virus-positive crude hospitalisation rates (per
1,000 children < 5 years old) were 14 for AdV, 9 for RSV, 6 for PIV, 4 for hMPV, 5 for influenza A, and 1 for influenza B. The annual crude rate of SARI hospitalisation was highest in children $<1$ year old (156 per 1000 children per year). Virus-positive hospitalisation

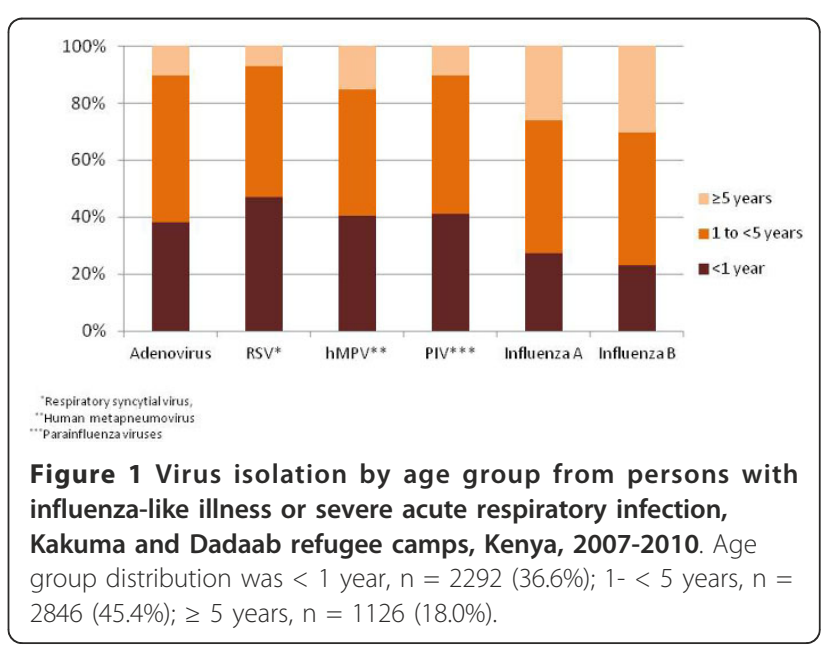


Table 2 Rates of SARI overall and by specific virus per 1000 children per year, Kakuma and Dadaab Refugee Camps, Kenya, 2007-2010

\begin{tabular}{|c|c|c|c|c|c|c|c|c|}
\hline & & $\begin{array}{l}\text { AdV } \\
\left(95 \% \mathrm{Cl}^{1}\right)\end{array}$ & $\begin{array}{l}\text { RSV } \\
\left(95 \% \mathrm{Cl}^{1}\right)\end{array}$ & $\begin{array}{l}\text { hMPV } \\
\left(95 \% \mathrm{Cl}^{1}\right)\end{array}$ & $\begin{array}{l}\text { PIV } \\
\left(95 \% \mathrm{Cl}^{1}\right)\end{array}$ & $\begin{array}{l}\text { Flu A } \\
\left(95 \% \mathrm{Cl}^{1}\right)\end{array}$ & $\begin{array}{l}\text { Flu B } \\
\left(95 \% \mathrm{Cl}^{1}\right)\end{array}$ & $\begin{array}{l}\text { SARI } \\
\left(95 \% \mathrm{Cl}^{1}\right)\end{array}$ \\
\hline \multirow[t]{3}{*}{ Kakuma } & $<1 \mathrm{yr}$ & $52.2(41.7-65.4)$ & $32.1(24.1-42.8)$ & $9.7(5.7-16.3)$ & $25.0(18.1-34.7)$ & $12.3(7.7-19.5)$ & $1.2(0.3-5.3)$ & $188.0(167.0-211.7)$ \\
\hline & 1 to $5 \mathrm{yrs}$ & $13.8(11.3-16.9)$ & $6.1(4.5-8.2)$ & $3.1(2.0-4.7)$ & $5.4(3.9-7.5)$ & $4.2(2.9-6.1)$ & $1.4(0.8-2.7)$ & $49.8(44.8-55.4)$ \\
\hline & $<5$ yrs & $20.6(17.7-23.9)$ & $10.7(8.6-13.1)$ & 4.2 & 8.9 & $5.6(4.2$ & $1.4(0.8-2.5)$ & $74.2(68.5$ \\
\hline \multirow[t]{3}{*}{ Dadaab } & $<1 \mathrm{yr}$ & $23.5(17.8-30.9)$ & $26.8(20.7-34.7)$ & $11.4(7.7-17.0)$ & $11.3(7.6-16.8)$ & $10.3(6.8-15.6)$ & $2.9(1.3-6.3)$ & $134.3(119.7-150.6)$ \\
\hline & 1 to $5 \mathrm{yrs}$ & $6.6(5.2-8.3)$ & $4.7(3.6-6.2)$ & $1.5(0.9-2.4)$ & $2.8(2.0-4.1)$ & $2.9(2.1-4.2)$ & $0.7(0.3-1.4)$ & $28.4(25.4-31.8)$ \\
\hline & $<5$ yrs & $9.5(7.9-11.3)$ & $8.5(7.0-10.3)$ & $3.2(2.3-4.3)$ & $4.3(3.3-5.6)$ & $4.2(3.2-5.5)$ & $1.1(0.6-1.8)$ & $46.5(42.9-50.4)$ \\
\hline \multirow[t]{3}{*}{ Overall } & $<\mathrm{yrr}$ & $35.0(29.4-41.7)$ & $29.0(23.9-35.1)$ & $10.7(7.8-14.7)$ & $16.8(13.1-21.6)$ & $11.1(8.2-15.1)$ & $2.2(1.1-4.4)$ & $155.9(143.5-169$. \\
\hline & 1 to $5 \mathrm{yrs}$ & $9.4(8.1-11.0)$ & $5.2(4.3-6.4)$ & $2.1(1.5-2.9)$ & $3.9(3.0-4.9)$ & $3.4(2.7-4.4)$ & $1.0(0.6-1.6)$ & $36.8(34.1-39.8)$ \\
\hline & $<5$ yrs & $13.8(12.3-15.5)$ & $9.3(8.1-10.8)$ & $3.6(2.9-4.5)$ & $6.1(5.1-7.3)$ & $4.8(3.9-5.8)$ & $1.2(0.8-1.8)$ & $57.4(54.3-60.8)$ \\
\hline
\end{tabular}

${ }^{1} 95 \%$ confidence Interval

crude rates per 1000 child-years for children $<1$ year old were 35 for AdV, 29 for RSV, 17 for PIV, 11 for hMPV, 11 for influenza $A$, and 2 for influenza $B$. The ratio of rates for children $<1$ year and 1 to $<5$ years old was 3.7:1 for AdV, 5.5:1 for RSV, 4.4:1 for PIV, 5.1:1 for hMPV, 3.2:1 for influenza A, and 2.2:1 for influenza B. The average crude SARI hospitalisation rates for children $<5$ years old were 1.6 times higher in Kakuma than in Dadaab $(p<0.001)$. The rates for AdV and PIV were $2.2(p<0.001)$ and $2.1(p<0.001)$ times higher for Kakuma than for Dadaab. The 2009 pandemic influenza A (pH1N1) was not associated with increased hospitalisation in either camp during the periods when $\mathrm{pH} 1 \mathrm{~N} 1$ was detected.

\section{Seasonal distribution}

In Dadaab, the rates for most viruses peaked from November to February (Figure 2). The rates of RSVassociated hospitalisation were highest during that time, with a minor increase in June. The rates for hMPV and influenza A peaked in November and December (Figure 3). PIV was mostly detected in January and February, and no distinct seasonal pattern was seen for AdV (Figure 3). In Kakuma, no distinct seasonality patterns were observed.

\section{Discussion and conclusions}

Our study suggests that viruses are a major cause of significant respiratory infections in two large refugee camps in Kenya; at least one virus was detected in specimens from $50 \%$ of the participants. Although data from UNHCR's Health Information System suggest that ARI is the highest cause of morbidity and mortality in the refugee camps, this is the first study that we are aware of to demonstrate the viral aetiologies of these infections. AdV and RSV were the leading pathogens identified, accounting for approximately two-thirds of viruses detected. As expected, rates associated with viral infection were highest for children $<12$ months of age $[4,6,35,36]$. The crude rates of hospitalisation per 1000 for SARI were more than four times higher for children $<1$ compared to children 1 to $<5$ years old.

Our findings for these two sites were similar to those reported from non-refugee populations in Mozambique, Gambia, Nigeria, South Africa, Indonesia, and India [37-39]. Rates per 1000 for severe infections due to RSV for children $<1$ year and $<5$ years of age were reported to be 15 and 9 (South Africa), 15 and 5 (Mozambique), and 16 and 10 (Indonesia) [39]. In a 3-year cohort study in rural India, severe lower respiratory tract infection (LRTI) rates per 1000 due to RSV for children aged < 1 , 1-2 years, and 2-3 years were found to be 14, 7, and 0 respectively [37]. In a meta-analysis of incidence of RSV associated severe LRTI in developing countries, Nair et al. estimated incidence in the $<1$ year age group per 1000 per year as 22 (95\% CI 9-53) [40]. Rates of respiratory virus infection in children $<5$-years-old in the two

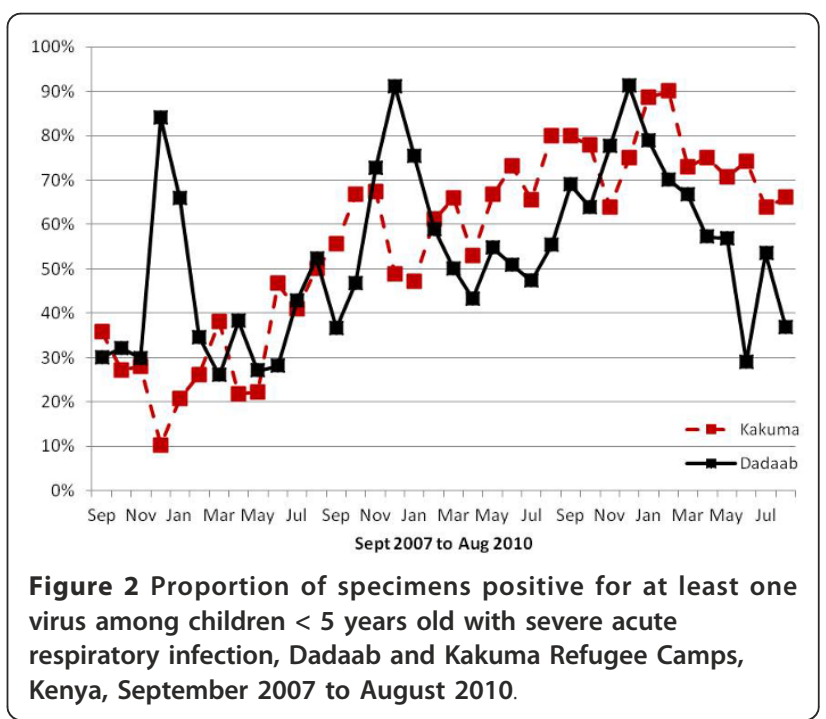




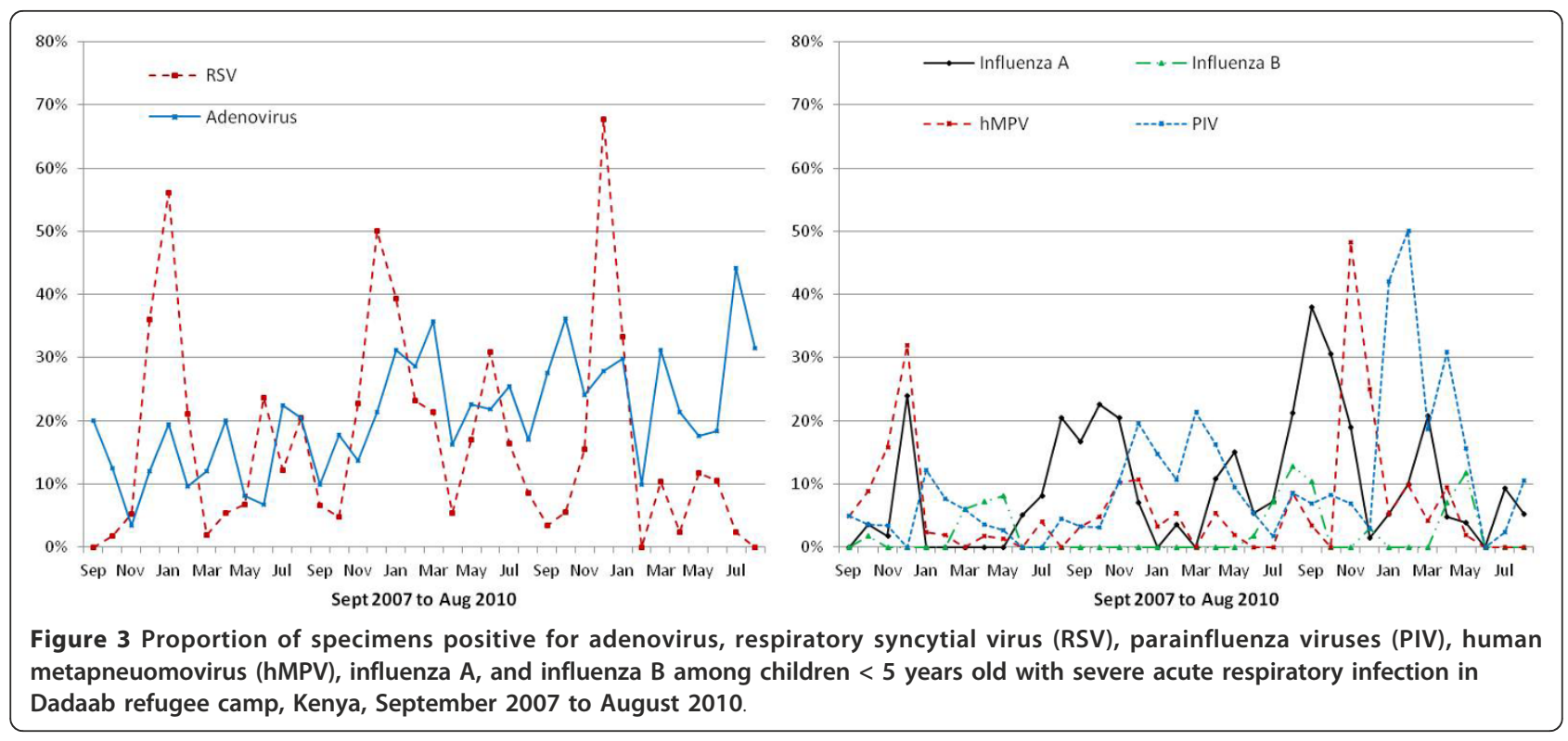

camps were $\sim 2$ times those reported for the United States or Europe but were similar to rates found in special populations groups within these countries $[4,41,42]$. For instance, in the United States, rates of hospitalisation for respiratory infections were found to be up to 5 times higher among Alaskan Native people than the US average [43].

The surveillance period overlapped with the 2009 pandemic influenza A (H1N1). While 2009 pH1N1 virus became the predominant circulating influenza A virus subtype, it was not associated with unusual rates in hospitalisation among the refugee population.

This study adds to our knowledge of the seasonal variations of respiratory viral infections in Africa. Even though both sites have very similar climatic conditions (arid and dry), we found remarkable differences in seasonal variation of ARI and specific virus activity, which might indicate varied transmission patterns in different subregions of the continent. There was distinct seasonality in Dadaab, with peak transmission occurring in November and December. Kakuma, on the other hand, despite having up to $60 \%$ more hospitalisation due to SARI, had no such seasonality. These differences may be due to the locations of the two camps. Kakuma, in the northwest of the country near the Ugandan and Sudanese borders, may reflect trends of viral transmission in the broader equatorial regions of central Africa, while Dadaab, located in the east near the Somali border, may reflect trends of transmission in the horn of Africa. Similar differences in seasonality between neighbouring tropical countries in Africa and Asia have been reported previously $[39,44]$. Additional surveillance points are required to further evaluate temporal variations of ARI due to viral illness.
Refugee populations are especially at risk for severe illness from respiratory infections [12,20,21]. Unique challenges make individuals residing in camp settings especially vulnerable to exposure to airborne diseases. The camp system of registration, food, water, and firewood distribution encourages crowding of large groups in small, confined spaces. In addition, malnutrition, high population density and poor shelter conditions may contribute to the elevated rates seen in this population. The availability of new, sensitive, reliable, and cost-effective technologies that can test multiple pathogens simultaneously from one easily obtainable specimen means that surveillance systems can now be set up for previously inaccessible populations [45].

Our study has several limitations: 1 ) Not all eligible individuals meeting the case definitions were identified, and not all those who were identified agreed to participate in the study. Thus the actual rates of SARI and virus infection associated SARI is likely higher than reported. 2) We did not attempt to collect data on all cases of ILI in the camp; therefore, we were not able to estimate rates of ILI. 3) Although the two hospitals are the only ones in the camps, refugees may have sought health care elsewhere; we did not capture information on health utilization among the refugees. If refugees did seek treatment elsewhere, our rates would again underestimate the actual rates. 4) The results of this study should also be interpreted with caution especially for pathogens e.g. AdV with known background carriage in healthy, asymptomatic individuals. Finally, the surveillance system was not designed to measure all indicators of ARI disease; due to lack of data, we could not estimate key outcomes, including mortality and duration of hospitalisation. 
Our study found that viruses are a major cause of respiratory infection in the two refugee camps. To decrease the burden of respiratory illnesses requires a multipronged interventional plan. Physical interventions like handwashing with soap have been found to decrease the odds of respiratory infection by as much $55 \%$, and nosocomial transmission has been shown to decrease by $66 \%$ when cohort nursing and wearing of gloves and gowns were introduced [46-48]. Measures could be put in place to minimise crowding, which is very common in refugee camps and has been associated with increased transmission of respiratory infections, and to target public health education messages during peak transmission months [49]. All SARI cases in this study were hospitalised in a ward shared by severely sick children presenting with other conditions. While we have not explored hospital acquired infection in this study, measures could also be taken to minimise potential nosocomial transmission. Because of the high rates of morbidity associated with these viruses in the refugee population, in addition to the implementation of innovative and effective approaches to achieve sustained compliance with hand hygiene promotions, refugees should be prioritised for vaccines when they become available [10,16-18] ARI prevention and control in refugee populations should be a key priority area for UNHCR, its partner agencies, and the international community.

\section{Acknowledgements}

We acknowledge our surveillance team in Kakuma and Dadaab, especially the surveillance officers who identified the cases and collected the specimens. We also acknowledge Abdinoor Haji, Adan Tepo, Milka Bunei, Hashim Abdullahi, Wamburu Kabura, and Dennis Odhiambo of CDC Kenya. Bilguissa Diallo of the German Technical Corporation (GTZ); Vincent Kahi, Milhia Abdelkader, James Ndirangu, and Philip Kandagor of the International Rescue Committee, Kenya; Dean Erdman of the Centers for Disease Control and Prevention, Atlanta, GA, USA.

Support for this activity was provided through cooperative agreements among the US Centers for Disease Control and Prevention, the International Rescue Committee, and the Kenya Medical Research Institute. This manuscript is published with permission of the director of the Kenya Medical Research Institute. The findings and conclusions in this report are those of the authors and do not necessarily represent the official position of the Centers for Disease Control and Prevention or other institutions with which the authors are affiliated.

\section{Author details}

${ }^{1}$ US Centers for Disease Control and Prevention, Nairobi, Kenya. ${ }^{2}$ Kenya Medical Research Institute, Nairobi, Kenya. ${ }^{3}$ US Centers for Disease Control and Prevention, Atlanta, GA, USA. ${ }^{4}$ United Nations High Commissioner for Refugees, Nairobi, Kenya. ${ }^{5}$ Ministry of Public Health and Sanitation, Nairobi, Kenya. ${ }^{6}$ International Rescue Committee, Nairobi, Kenya. ${ }^{7}$ KEMRI/CDC, Mbagathi Road off Mbagathi Way, KEMRI Compound, P.O. Box 606, Nairobi 00621, Kenya.

\section{Authors' contributions}

Conceived and designed the surveillance: RBE, RFB, MW, MAK, MKN, BKK, HB, $M Q, B S, B W$ and DM. Established the surveillance programmes: JAA, MN, AM, MAK, EA, MKN, MW, BKK, HB, RN, MQ, BS, BW, DM, RFB, RBE. Performed and interpreted laboratory tests: MKN, LWM. Analysis and interpretation of data: JAA, AG, EA, RN, MAK, RBE, RFB. Drafted the initial manuscript: JAA, MAK, AG,
RFB, RBE, MW, BKK, HB, RN, LWM, AM, BS. All authors contributed to and approved the final manuscript.

\section{Competing interests}

The authors declare that they have no competing interests.

Received: 11 September 2011 Accepted: 17 January 2012

Published: 17 January 2012

\section{References}

1. World Health Organization: World Health Report 2004 Statistical Anne Geneva: WHO; 2004.

2. Williams BG, Gouws E, Boschi-Pinto C, Bryce J, Dye C: Estimates of worldwide distribution of child deaths from acute respiratory infections. Lancet Infect Dis 2002, 2(1):25-32.

3. File TM: Community-acquired pneumonia. Lancet 2003, 362:1991-2001.

4. Iwane MK, Edwards KM, Szilagyi PG, Walker FJ, Griffin MR, Weinberg GA, Coulen C, Poehling KA, Shone LP, Balter S, et al: Population-based surveillance for hospitalizations associated with respiratory syncytial virus, influenza virus, and parainfluenza viruses among young children. J Pediatr 2004, 113:1758-1764.

5. Rudan I, Tomaskovic L, Boschi-Pinto C, Campbell H: Global estimate of the incidence of clinical pneumonia among children under 5 years of age. Bull World Health Organ 2004, 82:895-903.

6. Weber MW, Mulholland EK, Greenwood BM: Respiratory syncytial virus infection in tropical and developing countries. Trop Med Int Health 1998 3:268-280.

7. Acute Respiratory Infections. [http://www.who.int/vaccine_research/ diseases/ari/en/index.html].

8. Kusel M, de Klerk H, Kebadze T, Vohma V, Holt P, Johnston S, Sly P: Earlylife respiratory viral infections, atopic sensitization, and risk of subsequent development of persistent asthma. J Allergy Clin Immunol 2007, 119(5):1105-1110.

9. Weiss PF, Klink AJ, Luan X, Feudtner C: Temporal association of Streptococcus, Staphylococcus, and parainfluenza pediatric hospitalizations and hospitalized cases of Henoch-Schonlein purpura. J Rheumatol 2010, 37(12):2587-2594.

10. Centers for Disease Control and Prevention: Prevention and control of seasonal influenza with vaccines: recommendations of the Advisory Committee on Immunization Practices, 2009. MMWR 2009, 58:1-52.

11. Bustamante-Calvillo ME, Velázquez FR, Cabrera-Munõz L, Torres J, GómezDelgado A, Moreno JA, Munoz-Hernandez O: Molecular detection of respiratory syncytial virus in postmortem lung tissue samples from Mexican children deceased with pneumonia. Pediatr Infect Dis J 2001, 20:495-501.

12. Rudan I, Boschi-Pinto C, Biloglav Z, Mulholland K, Campbell H: Epidemiology and etiology of childhood pneumonia. Bull World Health Organ 2008, 86:408-416B.

13. Khan JS: Epidemiology of human metapneumovirus. Clin Microbiol Rev 2006, 19(3):546-557.

14. Weinberg GA, Hall CB, Iwane MK, Poehling KA, Edwards KM, Griffin MR, Staat MA, Curns AT, Erdman DD, Szilagyi PG, et al: Parainfluenza virus infection of young children: estimates of the population-based burden of hospitalization. J Pediatr 2009, 154(5):694-699.

15. East and Horn Africa 2008 Annual Report. [http://www.unher.org/ 4b506cca9.html].

16. Hall CB: Medical progress: respiratory syncytial virus and parainfluenza virus. N Engl J Med 2001, 344:1917-1928.

17. Teng MN: Live attenuated vaccines for respiratory syncytial virus. In Replicating Vaccines. Edited by: Dormitzer PR, Mandl CW, Rappuoli R. Basel: Springer; 2011:237-259.

18. Yu J, Kim S, Lee J, Chang J: Single intranasal immunization with recombinant adenovirus-based vaccine induces protective immunity against respiratory syncytial virus infection. J Virol 2008, 82(5):2350.

19. Turner $\mathrm{P}$, Turner $\mathrm{CL}$, Watthanaworawit W, Carrara VI, Kapella BK, Painter J, Nosten FH: Influenza in refugees on the Thailand-Myanmar border, MayOctober 2009. Emerg Infect Dis 2010, 16(9):1366-1372.

20. Ballard TJ, Neuman CG: The effects of malnutrition, parental literacy and household crowding on acute lower respiratory infections in young Kenyan children. J Trop Pediatr 1995, 41:8-13. 
21. Connoly MA, Gayer M, Ryan MJ, Salama P, Spiegel P, Heymann DL: Communicable diseases in complex emergencies: impact and challenges. Lancet 2004, 364:1974-1983.

22. Toole MJ, Waldman RJ: The public health aspects of complex emergencies and refugee situations. Annu Rev Public Health 1997, 18:283-312.

23. United Nations High Commissioner for Refugees: 2009 Global trends: refugees, asylum-seekers, returnees, internally displaced and stateless persons., Available from: http://www.unhcr.org/4c11fobe9.html.

24. Elias CJ, Alexander BH, Sokly T: Infectious disease control in a long-term refugee camp: the role of epidemiologic surveillance and investigation Am J Public Health 1990, 80(7):824-828.

25. Kim C, Nyoka R, Ahmed JA, Winchell JM, Mitchell SL, Kariuki Njenga M, Auko E, Burton W, Breiman RF, Eidex RB: Epidemiology of respiratory infections caused by atypical bacteria in two Kenyan refugee camps. $J$ Immigr Minor Health 2012, 14(1):140-145.

26. WHO Regional Office for Europe Guidance for Influenza Surveillance in Humans. [http://www.euro.who.int/_data/assets/pdf_file/0020/90443/ E92738.pdf].

27. Handbook: IMCI Integrated Management of Childhood Illness. [http:// whqlibdoc.who.int/publications/2005/9241546441.pdf].

28. Human Infection with Pandemic (H1N1) 2009 Virus: Updated Interim WHO Guidance on Global Surveillance. [http://www.who.int/csr/disease/ swineflu/WHO_case_definition_swine_flu_2009_04_29.pdf].

29. Kim C, Ahmed JA, Eidex RB, Nyoka R, Waiboci LW, Erdman D, Tepo A, Mahamud AS, Kabura W, Nguhi M: Comparison of nasopharyngeal and oropharyngeal swabs for the diagnosis of eight respiratory viruses by real-time reverse transcription-PCR assays. PLoS One 2011, 6(6):e21610.

30. Kodani M, Yang G, Conklin L, Travis TC, Whitney C, Anderson L, Schrag S, Taylor T, Beall B, Breiman R, et al: Application of TaqMan ${ }^{\circledast}$ low density arrays for simultaneous detection of multiple respiratory pathogens. J Clin Microbiol 2011, JCM. 02270-02210v02271.

31. CDC Protocol of Realtime RTPCR for Influenza A(H1N1). [http://www.who. int/csr/resources/publications/swineflu/CDCRealtimeRTPCR_SwineH1Assay2009_20090430.pdf].

32. Health Information System. [http://www.unhcr.org/pages/49c3646ce0. html].

33. Kirkwood BR, Sterne JAC: Essential Medical Statistics. 2 edition. Oxford: Blackwell Science; 2003.

34. Ulm K: A simple method to calculate the confidence interval of a standardized mortality ratio (SMR). Am J Epidemiol 1990, 131(2):373-375.

35. Mullins JA, Erdman DD, Weinberg GA, Edwards K, Hall CB, Walker FJ, Iwane $M$, Anderson $\sqcup$ : Human metapneumovirus infection among children hospitalized with acute respiratory illness. Emerg Infect Dis 2004, 10(4):700-705.

36. Hussey GD, Apolles P, Arendse Z, Yeates J, Robertson A, Swingler G, Zar HJ: Respiratory syncytial virus infection in children hospitalised with acute lower respiratory tract infection. S Afr Med J 2000, 90(5):509-512.

37. Broor S, Parveen S, Bharaj P, Prasad VS, Srinivasulu KN, Sumanth KM, Kapoor SK, Fowler K, Sullender WM: A prospective three-year cohort study of the epidemiology and virology of acute respiratory infections of children in rural India. PLoS One 2007, 2(6):e491.

38. Weber MW, Milligan P, Sanneh M, Awemoyi A, Dakour R, Schneider G, Palmer A, Jallow M, Oparaogu A, Whittle H, et al: An epidemiological study of RSV infection in the Gambia. Bull World Health Organ 2002, 80(7):562-568.

39. Robertson S, Roca A, Alonso P, Simoes E, Kartasasmita C, Olaleye D, Odaibo G, Collinson M, Venter M, Zhu Y: Respiratory syncytial virus infection: denominator-based studies in Indonesia, Mozambique, Nigeria and South Africa. Bull World Health Organ 2004, 82:914-922.

40. Nair H, Nokes DJ, Gessner BD, Dherani M, Madhi SA, Singleton RJ, O'Brien KL, Roca A, Wright PF, Bruce N: Global burden of acute lower respiratory infections due to respiratory syncytial virus in young children: a systematic review and meta-analysis. Lancet 2010, 375(9725):1545-1555.

41. Forster J, Ihorst G, Rieger CH, Stephan V, Frank HD, Gurth H, Berner R, Rohwedder A, Werchau H, Schumacher M, et al: Prospective populationbased study of viral lower respiratory tract infections in children under 3 years of age. Eur J Pediatr 2004, 163(12):709-716.

42. Hall CB, Weinberg GA, Iwane MK, Blumkin AK, Edwards KM, Staat MA, Auinger $P$, Griffin MR, Poehling KA, Erdman D, et al: The burden of respiratory syncytial virus infection in young children. N Engl J Med 2009, 360(6):588-598.

43. Singleton RJ, Bruden D, Bulkow LR, Varney G, Butler JC: Decline in respiratory syncytial virus hospitalizations in a region with high hospitalization rates and prolonged season. Pediatr Infect Dis J 2006 25(12):1116-1122.

44. Chan PWK, Chew FT, Tan TN, Chua KB, Hooi PS: Seasonal variation in respiratory syncytial virus chest infection in the tropics. Pediatr Pulmonol 2002, 34(1):47-51.

45. Grondahl B, Puppe W, Hoppe A, Kuhne I, Weigl J, Schmitt H: Rapid identification of nine microorganisms causing acute respiratory tract infections by single-tube multiplex reverse transcription-PCR: feasibility study. J Clin Microbiol 1999, 37(1):1-7.

46. Jefferson T, Del MC, Dooley L, Ferroni E, Al Ansary LA, Bawazeer GA, van DML, Nair S, Foxlee R, Rivetti A: Physical interventions to interrupt or reduce the spread of respiratory viruses. Cochrane Database Syst Rev 2010, 1, doi:10.1002/14651858.CD14006207.pub14651853.

47. Madge P, Paton JY, McColl JH, MacKie PLK: Prospective controlled study of four infection-control procedures to prevent nosocomial infection with respiratory syncytial virus. Lancet 1992, 340:1079-1083.

48. Luby SP, Agboatwalla M, Feikin DR, Painter J, Billhimer W, Altaf A, Hoekstra RM: Effect of handwashing on child health: a randomised controlled trial. Lancet 2005, 366(9481):225-233.

49. Graham NM: The epidemiology of acute respiratory infections in children and adults: a global perspective. Epidemiol Rev 1990, 12:149.

\section{Pre-publication history}

The pre-publication history for this paper can be accessed here: http://www.biomedcentral.com/1471-2334/12/7/prepub

doi:10.1186/1471-2334-12-7

Cite this article as: Ahmed et al:. Epidemiology of respiratory viral infections in two long-term refugee camps in Kenya, 2007-2010. BMC Infectious Diseases 2012 12:7.

\section{Submit your next manuscript to BioMed Central and take full advantage of:}

- Convenient online submission

- Thorough peer review

- No space constraints or color figure charges

- Immediate publication on acceptance

- Inclusion in PubMed, CAS, Scopus and Google Scholar

- Research which is freely available for redistribution

Submit your manuscript at www.biomedcentral.com/submit
C Biomed Central 